\title{
Public space in an age of austerity
}

\author{
Matthew Carmona ${ }^{1} \cdot$ Gro Sandkjær Hanssen ${ }^{2} \cdot$ Bettina Lamm $^{3} \cdot$ Katarina Nylund ${ }^{4} \cdot$ Inger-Lise Saglie $^{5} \cdot$ Anne Tietjen $^{3}$
}

Published online: 15 February 2019

(c) The Author(s) 2019

\begin{abstract}
Through an overview of the decade 2008 to 2017, and looking comparatively across four northern European cities, this paper reflects on the changing nature of public space during these austerity years and on the processes of shaping public spaces. The paper draws from the experiences of London, Copenhagen, Malmo and Oslo to explore processes of the design, development, use and management of public spaces during this period. The evidence suggests that we have witnessed a period of significant innovation, side by side with major challenges to the collective approach to public spaces. This has led to distinct forms of public spaces that for good or ill have multiplied as a result of the trends discussed in the paper, spaces of; expectation; the private/public sphere; spectacle; respite; infrastructure; diversion; income generation; security; the ephemeral city; community control; occupation; disadvantage; and decline. Episodes of changing practice are set out in the paper and cumulatively reveal distinct and significant changes during the austerity era, although not necessarily in the manner that might have been expected. Instead, in these four cities, the impact of austerity seems to have been eclipsed by other evolving and competing public policy goals, and by the evolving range of public space types.
\end{abstract}

Keywords Public space $\cdot$ Austerity $\cdot$ Innovation

\section{Introduction}

Since the financial crisis of 2008 governments, municipalities, developers and ultimately communities have had to rapidly adapt to a new more uncertain reality. Some argue that the period has marked a new and distinctive era with its own political-economy, governance and societal norms (Bramall 2013 , pp. 84-110). For others the period is simply a continuation, perhaps even a deepening, of the neo-liberal project

Matthew Carmona

m.carmona@ucl.ac.uk

1 The Bartlett School of Planning, UCL, London, UK

2 Norwegian Institute of Urban and Regional Research, Oslo and Akershus University College of Applied Sciences, Oslo, Norway

3 Section for Landscape Architecture and Planning, Department of Geosciences and Natural Resource Management, University of Copenhagen, Copenhagen, Denmark

4 Department of Urban Studies, Malmö University College, Malmö, Sweden

5 Department of Landscape Architecture and Spatial Planning, Norwegian University of Life Sciences, Ås, Norway
(Bone 2012); a project that has frequently been underestimated as regards its capacity for transformative and adaptive change (Peck and Tickell 2002, p. 400); and which continues to thrive (albeit evolving) both within its heartlands (e.g. England) and as modified by a Scandinavian welfare sensibility (Peck and Tickell 2002, p. 387): both the subject of this paper. In each case, the impact on public spaces, as the discussion will show, is not always what might be expected.

Winston Churchill argued that we should "never let a good crisis go to waste". Reflecting Churchill's maxim, in times of crisis some evidence exists of a flowering of ideas and practices relating to public spaces as the most quintessentially shared parts of our built environment. Smog filled Victorian cities, for example, saw a flowering of public parks, Europe's bomb-ravaged post-war cities saw the new forms of expansive Modernist public space take root, and the economic shocks of the 1980s led to private corporations rediscovering the commercial value of traditional public spaces such as at London's Canary Wharf.

Whilst others have written about what has been christened 'austerity urbanism', this discourse often focuses more on the governance and political impacts of austerity in urban areas, rather than on its spatial implications (e.g. Peck 2012; Mayer 2013). Therefore, looking back over the past eight 
years, this paper asks, has a 'good crisis' gone to waste? To do so it explores how the austerity context has impacted on the design, delivery, use and management of public spaces in four northern European cities-London, Copenhagen, Oslo and Malmö. Whilst of contrasting scales, ${ }^{1}$ these cities are similar climatically and each boasts a history common to many European cities in which formal public spaces have long been a staple of the urban fabric and range from grand civic squares, to neighbourhood market places; parks and gardens to the communal spaces of post-war housing estates. They sit alongside the everyday streets and civic infrastructure of urban and suburban neighbourhoods.

The four are each relatively prosperous and growing cities with mature systems of urban management. In this respect the context is quite different to some other parts of Europe where recession, alongside austerity, has been far deeper and more sustained in its impacts (Christodoulou and Lada 2017, p. 144). It is also different from many cities beyond Europe where private/public power relationships, systems of urban management, and the emphasis on public space may be profoundly different.

Despite their differences in scale and global and even national significance, the four cities have in common a recent history of embracing the importance of public space, and public policy aspirations for public spaces that have become ever more sophisticated. In contrast to earlier eras where formal public spaces were largely created for civic, welfare reasons, or for narrow private profit, today, as the discussion will show, investment in public space is associated with a new and complex set of public policy priorities around health, sustainability, resilience, liveability, the social integration of diverse populations and, the economic competitiveness of host cities. Urban renaissance (more or less explicitly) has been a key theme of each city with many new spaces being created or recreated within the existing (and increasingly) dense urban fabric, and as part of a larger public and private re-investment in urban areas.

\section{The approach}

The research underpinning this paper utilised a qualitative heuristic dialogue to explore the topic, with programmed face to face expert interchanges between the authors supplemented by the collection of local examples of the phenomena explored, selected interviews with local stakeholders, and then comparison across the cases study cities against a preconceived analytical framework. No attempt was made to systematically compare every aspect of the discussion against all four cities, and instead issues are discussed,

\footnotetext{
${ }_{1}^{1}$ Respectively approximately $8.7,2.4,1.3$ and 0.7 million people live in the in the four metropolitan areas.
}

evidence cited, and comparisons made in a largely exploratory manner.

In this case, the framework chosen was the place-shaping continuum set out by Carmona (2014a, b). The paper represents a journey across that continuum, from the design and development, to the use and management of public spaces, drawing out conclusions about the shifting power relationships in the four cities during the austerity years. Unfortunately, whilst each city has a rich history of public space creation, space does not permit a full contextualisation of the discussion within this sweep of history. Instead the discussion begins with a brief introduction to the contemporary politics and practices of public spaces of the four cities during this neo-liberal era. Neither does space permit the rehearsal of the extensive literature on the nature of public space and how and for what purposes it is defined. Instead, for the purposes of this research public space was simply taken to mean all those parts of the city, regardless of ownership and management responsibility, to which the public (typically) has free and unrestricted access.

\section{The changing context of four cities}

\section{Agnostics and advocates}

Analysis begins with a brief exploration, city by city, of the changing and varying political and policy context for public spaces and how these have responded to the drive for austerity. As a political and policy concern, issues relating to the provision and quality of public space have been on the rise, globally. As De Magalhães and Carmona (2009, p. 111) explain: "From civic, leisure or simply functional spaces with an important, but to some extent discrete, part to play in cities and urban life, public spaces have become urban policy tools of a much wider and pervasive significance", often at the forefront of policy debates around liveability, sustainability, social inclusion, economic competitiveness, place image and culture.

Whilst some question the contemporary relevance of public spaces "in an age of urban sprawl, multiple usage of public space and proliferation of sites of political and cultural expression" (Amin 2006), this has not generally been taken up by politicians (either nationally or locally) for whom public spaces are typically a binary concern. Either they are off the agenda completely - a public space 'agnostic view' and therefore of little relevance beyond their management cost and maintenance liability, or they are a major opportunity with far reaching economic, social, cultural, health and environmental potentials—a public space 'advocate view'. 


\section{London}

London, the largest of the four cities, demonstrates this binary approach well and, reflecting the diversity of initiatives in recent years in the city, features heavily in the comparison that follows. The 1980s and 90s was a time of disinvestment and decline as regards the publicly owned streets and spaces of the city which were largely viewed, in a purely managerial sense, as traffic arteries. This changed after 2000 and the election of the first London Mayor-Ken Livingstone-when public spaces moved decisively up the policy agenda. Livingstone argued that the quality of public space had a direct impact on the city's beauty, sustainability, connectivity and safety-and therefore on its attractiveness to investors-and promised to create or upgrade 100 public spaces over 5 years. For Londoners this was undeniably a period when a noticeable new embrace of public space was apparent as café culture came to the city, but the complexities of delivering public spaces schemes meant that Livingstone's early ambition proved rash and only five schemes were realised by the end of his tenure (Carmona 2012, p. 37).

Boris Johnson, the second mayor, came to power in May 2008 just as the grip of austerity began to tighten. His early emphasis was on leafy outer London, and he actively embraced austerity, even before it began to bite nationally (after 2010). Consequently, Johnson quickly set about dismantling the high-profile public space programmes of his predecessor, including a plan to re-design Parliament Square, he disbanded Design for London (the Mayoral design team), and announced the closure of the London Development Agency; previously a major source of project funding. Yet Johnson also inherited responsibility for delivering the London Olympics in 2012 and stimulating the housing market in London that had crashed spectacularly in 2009. These priorities, alongside his political concern for outer London (notably their struggling high streets) and penchant for innovative projects, meant that, despite contrary signs at the start, he also quickly embraced a strategic public spaces role for the city. In fact he continued to invest heavily in public spaces throughout the austerity years (Carmona 2012, p. 38) (Fig. 1).

The third mayor-Sadiq Khan — has promised to continue the focus on public spaces although with a stronger environmental emphasis directed at reducing pollution, clutter and congestion, and improving design. ${ }^{2}$ Begun under Johnson but significantly bolstered from 2016 under Khan, much of the discussion on London's streets and spaces is increasingly seen in health terms, with the launch of Healthy Streets for London in early 2017 formalising a range of initiatives into

\footnotetext{
$\overline{2}$ http://www.sadiq.london/a_greener_cleaner_london
}

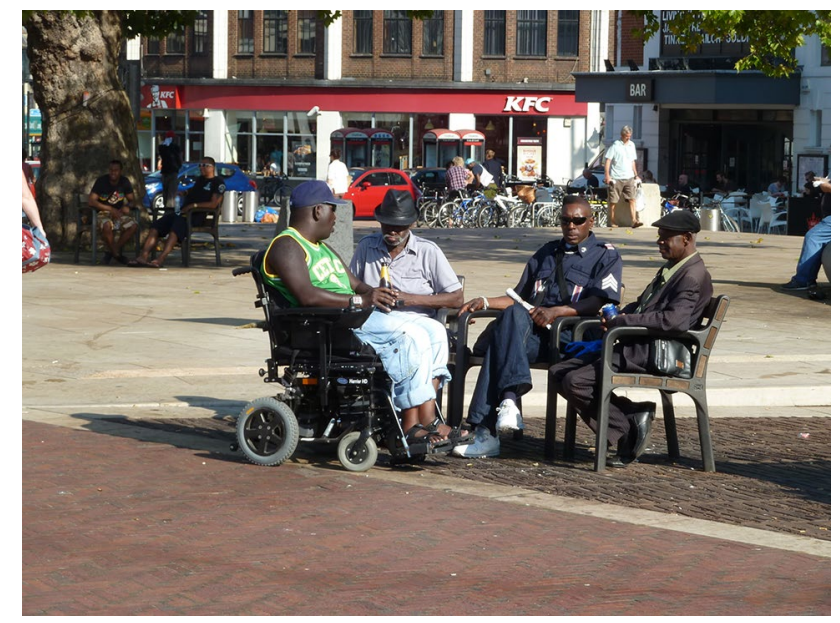

Fig. 1 Windrush Square, Brixton: Boris Johnson also benefitted hugely from the legacy of work on public spaces conduced during the Livingstone era, as, like the gift that keeps on giving, public space projects continued to mature throughout the austerity years (Matthew Carmona)

a long-term plan and directing the $£ 2.1$ Billion of streets spending over the Mayoral term "towards delivering against the Healthy Streets Indicators" (Transport for London 2017).

\section{Copenhagen}

After a period of urban decline in the 1970s and 80s, since the 1990s Copenhagen has been in a strategic urban renewal phase (Bisgaard 2010). In this, public space development has played a major role not only in the city centre but also in the revitalisation of residential neighbourhoods and, more recently, in the redevelopment of post-industrial areas. Indeed Copenhagen was one of the first cities to establish an explicit public space advocate regime with the 2006 urban space action plan (City of Copenhagen 2006a, b). By 2008, Monocle named Copenhagen the best of the World's most Liveable cities (City of Copenhagen 2009, p. 3). 2008 was also the year in which the global financial crisis hit Denmark with a 7\% fall in GDP in just a year and severe consequences for the public finances. In parallel the Danish housing market crashed, and it was not until 2012 that the market picked up again (Realkreditrådet 2016).

Despite this, the city of Copenhagen maintained a proactive urban development policy and made extensive public investments throughout the crisis years, specifically in the design, construction and maintenance of public urban space. In 2010, the city launched the initiative 'Kickstart Copenhagen' to "invest itself out of the crisis" and at the same time raised the budget for public construction work to continue developing "an attractive, growing city" and to create job opportunities (Kickstart København 2010, p. 2). This built on the city's first urban life policy 'Metropolis for People' 
which set out a vision for urban life and public space development with three main goals and measurable objectives: (i) more urban life, (ii) more walking, and (iii) more people to stay longer (City of Copenhagen 2009, p. 2). Theoretically and methodologically the vision was based on the work of Jan Gehl, whose office was consulted by the municipality on the policy.

Although this vision remained intact throughout the crisis years; the follow-up policy 'Community Copenhagen' in 2015 marked a significant shift towards more iterative and co-creative processes. Where 'Metropolis for People' emphasised the provision of attractive public spaces and measurable objectives for their performance; the current policy focuses on creating possibilities for citizens to become more engaged in the design and maintenance of public spaces and to develop urban life activities in the public realm. It advocates less control over the appearance of public spaces and the activities taking place in them and encourages "more of an edge" when compared to the extremely designed and programmed public spaces of the early 2000s (City of Copenhagen 2015a, p. 2). City branding still plays an important role in the current policy, but Copenhagen now strives for a better everyday life experience in its urban neighbourhood spaces with sustainable urban development and resilience writ large as overarching objectives for public space projects.

\section{Oslo}

Norway faired better than many European countries following the 2008 financial crisis, using its huge sovereign wealth fund to support the economy following a recession in 2009. The period saw significant attention on the city's waterfront areas, with much discussion about the role these were playing in rebranding the city internationally (Røe 2015). Western harbour developments, for example at Tjuvholmen, were complemented by developments in the eastern harbour characterized by landmark buildings (such as the Barcode development), new public spaces (including a waterfront promenade), and temporary and permanent arts and cultural installations (e.g. the Opera House and Museum of Modern Art). Whilst intended to increase the attractiveness of the new areas, some argue that project have been unduly targeted at affluent groups and exclude others (Bergsli 2015; Røe 2015). Separately there has been a policy to encourage investment in specific deprived areas, notably the outer eastern part of the city-Groruddalen. This area features high-rise functionalist blocks from the 1960/70s and storage and logistics areas, now with new outdoor spaces, parks, and meeting places inserted between.

A strict densification policy reflects the city's position surrounded by green areas protected by national law (Hanssen et al. 2015) and this has increasingly led to a tension between the desire for higher density housing and for high-quality outdoor public spaces (Lipton 2004; Guttu and Schmidt 2008). The situation has been exacerbated by the financial situation and the resulting tight municipal budgets which encouraged a sell off of property by various state actors (railway, harbour, public transport lands, etc.). The funds were invested in new and rehabilitated social infrastructure for the city's increasing population but have resulted in an increasing shortage of municipal land for open space as the city becomes more compact. To a greater extent than ever before the city authorities now rely on the market to deliver such space, and to do so have developed a range of more sophisticated design governance tools (Selvig 2015; Sirowy 2015). These include:

- A Plan for Public Spaces and Meeting Places, adopted in 2009

- Informal area-based plans for public spaces (VPORs) to deliver blue/green structures and public spaces

- Economic models for sharing the cost of public spaces among different property owners in VPOR areas

- Development agreements between the city and property owners covering responsibility for funding new public spaces.

From 2015, a new left-leaning city government has focused on the environment. As part of a plan to slash emissions of greenhouse gases by 50\% by 2020 (compared to 1990 levels), a ban is to be instigated on private vehicles in the city centre. ${ }^{3}$ The car-free zone will be the biggest in Europe with parking-free streets becoming new high-quality public spaces. From the 1990s on, Oslo has increasingly been in the camp of public space advocate, but if the current plans come to fruition, the changes to the city centre will be far more dramatic than anything attempted before.

\section{Malmö}

Like Norway, the global financial crisis affected Sweden less than other OECD countries (OECD 2011), but Sweden had entered an age of austerity long before following its industrial crisis of the early 1990s. In Malmö, the smallest of the cities examined in this paper, the earlier crises led the social democratic Mayor, Ilmar Reepalu, to instigate a new strategy designed to move Malmö from an industrial society agnostic about questions of urban quality to a knowledge economy where such issues matter (Dannestam 2009; Nylund 2014). The resulting urban policy led to significant investments in the city, including the establishment of new public spaces

\footnotetext{
3 https://www.theguardian.com/environment/2015/oct/19/oslo-moves -to-ban-cars-from-city-centre-within-four-years
} 


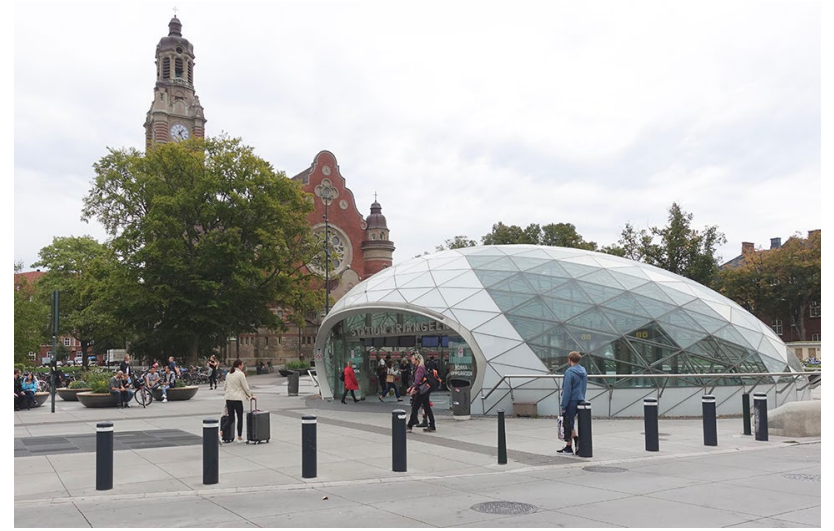

Fig. 2 Triangeln, Möllevången: a new public space dating from 2010 in the centrally located dense working class district of Möllevången (Matthew Carmona)

that have been acknowledged internationally for their quality (Fig. 2), and that have helped to attract high-income groups from surrounding municipalities. During the 2000s, municipal investments in technical infrastructure amounted to around two billion SEK each year (from a total annual municipal budget of 17 billion SEK-Malmö stad 2016). To finance this, the city sold the Sydkraft public power plant (Holgersson 2014, p. 10) and utilised money from the pension fund set aside for its pre-1998 employees. ${ }^{4}$

While these economic assets enabled the city to transform itself, arguably they also contributed to growing social inequalities with private investment eschewing less prosperous parts of the city (Salonen 2012; Andersson et al. 2007), and the city unable to afford the new social infrastructure that the resulting population growth-2.6\% annually (Malmö stad 2015a) — demands. ${ }^{5}$ By 2012, the earlier funding was used up and from 2013 the city was forced to borrow new money and to lever its extensive land holdings as an economic asset (Malmö stad 2014, p. 7; 2016, p. 33). This sparked debates about the many competing demands that the city faces and in 2013 the Social Democrat, Karin Stjernfeldt Jammeh, was elected as Mayor and announced that her priorities would be to invest in the social infrastructure of the city.

Despite the change, decisions taken in the past restrain current choices, and discussion of the Malmö case in this paper largely focuses on the city's most recent public space project, Malmö Live, completed in 2015. This centrally located concert hall, congress centre and hotel followed a protracted planning process and raised questions (also apparent in the other cities), concerning who is public space for. At its heart was the idea of establishing a new public space

\footnotetext{
4 interview, Economy Director, City of Malmö.

5 interview, Manager of Budgetary Control, City of Malmö.
}

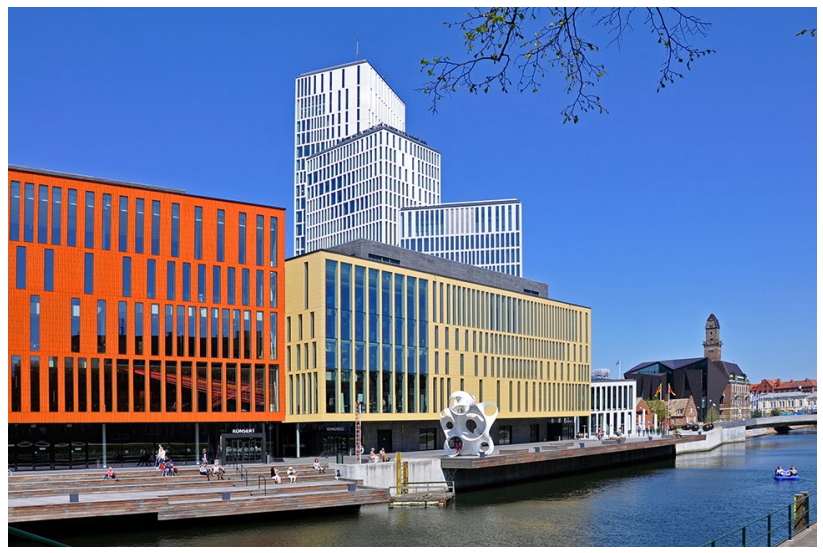

Fig. 3 Malmö Live, University Island: In the foreground is the concert hall with 1700 seats next to the congress center with a capacity for 1500 participants, and in the background is the hotel with 444 rooms (Tyke Tykesson)

in the form of an urban living room for the city. The notion was based on the idea of a 'Fourth Place' which consultants Per Riisom and Hanne Beier Sörensen had advocated to the city as the logical evolution of Ray Oldenburg's (2000) concept of the Third Place. This envisaged a form of hybrid space that was at one and the same time both public and private but accessible for all (Malmö stadsbyggnadskontor 2009 , p. 28; p. 6). The strong focus on the role of Malmö Live as a meeting place reflected the determination of the municipality to use this new arena as a test bed for the idea.

\section{Agnostics to advocates}

With different trajectories, all four of the case study cities have witnessed a journey from an agnostic (managerial) perspective to a role as advocate with regard to the merits of public space investment, sometimes for classic entrepreneurial reasons (Biddulph 2011), but increasingly for social ones. Whilst this belief seems to have persisted during the austerity years, the discussion of the changing political and policy context of the four cities indicates that it has also been evolving as part of the larger neo-liberal project that Peck and Tickell (2002, p. 381) characterise (through gritted teeth) as the "commmonsense of the times". Thus just as the wider political-economy of each city has continued to evolve, so to have approaches to public space.

The discussion that follows pulls this apart and, by comparatively identifying trends in the design, development, use and management practises across the four cities, determines whether there are any significant common threads that can be detected during the austerity years. 


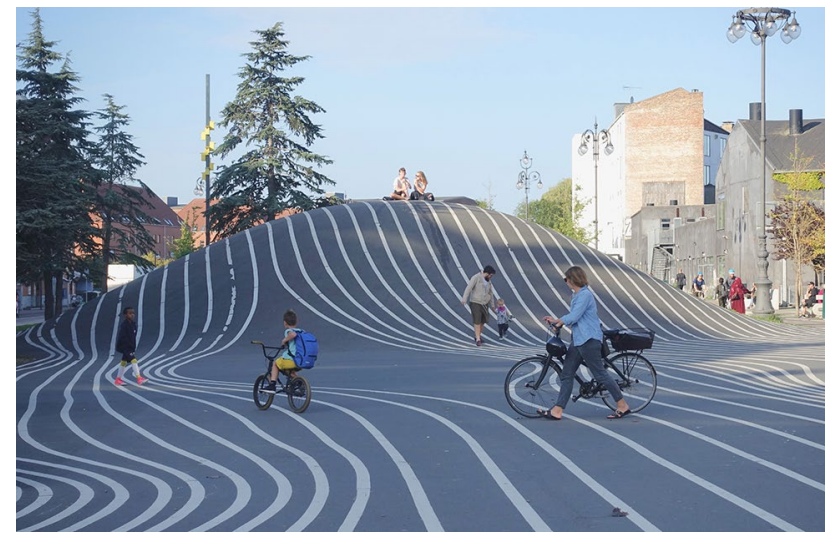

Fig. 4 Superkilen features a daring design through its bright red urban carpet, black plaza and green belt, each furnished with urban elements from around the word mirroring the multi-cultural population of the neighbourhood (Matthew Carmona)

\section{Design}

\section{Space as spectacle}

As already noted, public space quality is often placed in the vanguard of perceived needs for cities to compete with each other globally, and the architectural competition is a common means to achieve this (Strebel and Silberberger 2017). Malmö Live represents a classic case; part of the city's attempts to re-position itself economically (Fig. 3). Here, a design/development competition was instigated to select the scheme (Malmö stad 2010a, p. 26), although, reflecting the straightened times, the winning solution also turned out to be the cheapest (600 million SEK-Sydsvenskan 2015).

Pre-crisis, the City of Copenhagen had a major focus on developing and renewing public spaces through ambitious design schemes based on international competitions. Its 2006, urban space action plan prescribed a double strategy of metropolitan projects in the city centre and local projects in residential neighbourhoods to upgrade existing areas and create a number of new, unique urban spaces (City of Copenhagen 2006a, b, p. 12). Among many spectacular and costly examples are six strategic projects in the Metropolzone area; the renovation and re-design of the Købmagergade pedestrian street; and the redesign of Nørrebro Station and Israels Square. During this process even local projects exhibited a tendency towards spectacular design and international branding, including the acclaimed public park Superkilen in Nørrebro (Fig. 4) and the re-design of a series of public spaces along Sønder Boulevard in Vesterbro. Although conceived before 2008, most of these were constructed and opened in the midst of the financial crisis.

In London, playing on the then Mayor's love of the dramatic (he funded, for example, the Emirates Air Line cable

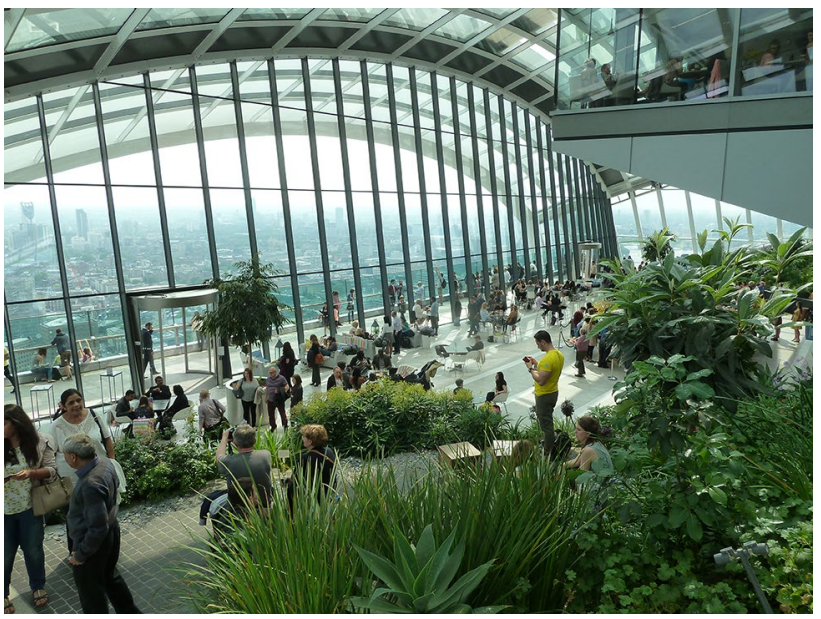

Fig. 5 The new 'public space'-Sky Garden—on top of the Walkie Talkie tower negotiated as part of the planning permission. Free to enter, but you need to book in advance, obtain a ticket, and pass through security (Matthew Carmona)

car across the Thames), the crisis years encouraged developers and others to see the potential of public spaces as places of spectacle. In 2011, for example, the Mayor was quick to champion Gensler's ultimately unrealised plans for a floating boardwalk along the Thames, plans that were criticised for 'privatising' parts of the river. He also approved revised plans for the now realised Walkie Talkie tower in the City of London that, in exchange for the planning permission, delivered London's first ticketed 'public' space at the top of the 36 storey tower (see Fig. 5). Elsewhere he strongly backed the Garden Bridge Trust with $£ 60$ million of public money to deliver its garden bridge across the Thames; a scheme that some argue was ostensibly a private tourist attraction rather than a public space (Minton 2014) and which has since been abandoned by Johnson's successor-Sadiq Khan. Each, for good or ill, extended traditional notions of public space (Cho et al. 2016) whilst creating or envisaging new ways of experiencing the city with associated knock-on public interest and/or commercial benefits.

\section{Investing in the ordinary}

Whilst spaces of spectacle continue to be produced in each of the cities, a second trend has focussed on 'everyday' spaces. London represents a case-in-point where many of the city's streets have suffered from decades of priority being given to traffic over people (Gehl Architects 2004). Whilst there have been individual examples of re-prioritising space in favour of pedestrians (e.g., Kensington High Street), only recently has the approach been mainstreamed by Transport for London. Thus, since 2014, London's streets have been re-classified against a nine-part matrix that, to varying degrees, recognises each as a 'place' as well as a corridor 




Fig. 6 Bjerkedalen Park, has undergone a renewal with new walkways, abundant plant life, a café and spaces for activities and recreation. The Hovinbekken brook has been opened up and flows through the entire park (Helge Høifødt)

for 'movement'), ${ }^{6}$ and this will now define design standards across the city. Gradually (very gradually), a re-balancing of ordinary street space is occurring (TfL 2013, 2016).

While Copenhagen even raised its budget for public urban space projects during the austerity years, the city is increasingly moving away from high-profile public realm schemes towards everyday maintenance and functional adaptations to existing public spaces. This marks a significant political shift towards what is labelled 'everyday-life-functionality', with politicians preferring to be seen solving the city's more tangible urban problems such as flooding or safe cycling. However, this does not mean that the city now only pursues technical solutions to urban problems. Investments in cloudburst management, for example, are being tied in with the development of more attractive public spaces in innovative ways, including Copenhagen's first climate resilient neighbourhood; Skt. Kjelds (City of Copenhagen 2012a) and public spaces and recreational opportunities are being weaved into the planning of bicycle pathways across the city.

A similar multi-functional approach is seen in Oslo where the health impacts of public space design are now well established as a driver of practice, leading to a strong focus on the recreational opportunities provided by public spaces. This emphasis was reinforced in statute in 2008 and 2011 and is increasingly reflected in design strategies that include the instillation of outdoor gym equipment, and the integration of blue/green spaces for ecological, recreational, aesthetic and management purposes (Saglie and Thoren 2014) (Fig. 6). ${ }^{8}$ Green corridors (marka), for example, are being planned to

\footnotetext{
6 https://tfl.gov.uk/info-for/boroughs/street-types?intcmp=24919.

7 Interview, Head of public space development, City of Copenhagen.

8 https://no.m.wikipedia.org/wiki/Fil:Bjerkedalen_med_bro.JPG
}

extend from the inner city to the surrounding outdoor recreational areas to encourage walking, cycling and recreation (Ministry of Modernization and Local Government 2016).

\section{The challenges of densification}

Public spaces are also playing a key role in the everyday processes of growth and densification across the cities. With their tightly drawn growth boundaries, Oslo and London exemplify this. In Oslo, the need to redevelop ex-industrial areas frequently begins with the establishment of public spaces, but because densification is leading to a greater concentration of people living in inner city areas, spaces are now subject to more intensive use for a greater range of purposes (mobility, play, barbecues, events, swimming, jogging, etc.). Building at higher densities has also put pressure on the provision of private (including communal) outdoor spaces in new residential developments, particularly in central locations where prices have been rising dramatically. As it is a political goal to build more flats, developers have been arguing for a higher proportion of small flats $(35 \mathrm{~m} 2)$ and for an easing of requirements relating to sunshine penetration into private outdoor spaces (Boligvekstutvalget 2016). They argue instead that the provision of public outdoor spaces can replace the need, sparking debates about the appropriate size and distance (from homes) of any such provision.

In London, successive iterations of the London Plan have supported densification in areas well served by public transport and in the city's strategic opportunity areas, and a quid pro quo for this has been the provision of high-quality public spaces. The results have sometimes proved controversial, including the 2009 re-design of Chelsea Barracks where a scheme by Richard Rogers became mired in controversy following a damming intervention by Prince Charles and was subsequently replaced by traditional terraces and mansion blocks around a series of garden squares (Adams 2010). In 2017, battle raged over rival plans to redevelop the huge Mount Pleasant sorting office. On the one hand, contemporary medium and higher rise blocks and a linear park was proposed, and this was pitched against, on the other, traditional mansion blocks and a central classically designed square. Elsewhere, much larger regeneration projects at Stratford and Nine Elms are being planned around the city's first significant new urban parks since Victorian times, whilst the regeneration (aka replacement) of post-war housing estates are substituting unloved indeterminate land oozes, as Jane Jacobs (1961) once christened them, with diverse 'contained' green infrastructure that sometimes blurs the boundaries between public and private (GLA 2015, p. 33). This gradual densification of the sorts of low-density cities that predominate in Northern Europe means that public spaces are having to work a lot harder than they have before. 


\section{Development}

\section{Big business, 'private' spaces}

Traditionally, public space is thought of as a public good, paid for, delivered and managed by the public purse, but all four cities demonstrated that this was frequently not the case.

In Copenhagen, for example, a number of public-private development models for public spaces are common in terms of project organisation, financing and ownership. Most of the city's high-profile branded public spaces were initiated by the municipality as public projects but developed together with private foundations who have played a decisive role in the programming and design of these spaces. Lokale-og Anlægsfonden, for example, which was established by Danish sports organisations, has been leading on the provision of recreational spaces for activity, fitness and play, while Realdania has co-financed a broad range of significant and strategic public space projects. Since the 1990s, many largescale urban redevelopment projects have been led by the publicly owned but profit-oriented urban development company, By og Havn, ${ }^{9}$ or entirely by private development companies, including Carlsberg City. In such places, increasing attention has been paid to 'establishing the place' through developing public spaces that encourage a more public life.

Malmö Live represents perhaps the quintessential public/private project, all the more significant because of the impact of this very large project on the smallest of the cities discussed in this paper. In 2010, the city council accepted an agreement (Malmö stad 2010b) in which Skanska AB took responsibility for construction of the 906 million SEK project (Malmö stad 2010b, p. 13). Amongst other factors leading to the rise in costs was an $18 \%$ increase in the size of the concert hall to better accommodate the key public space (Sydsvenskan 2015), the foyer. This was envisaged to be an Urban Common, or a meeting place furnished with sofas and armchairs and free Wi-Fi, where people could meet without consuming: a 'new living room for the city'. The escalation in costs led to questions in the local media and a political crisis, with many arguing that in times of austerity, the project was costing too much. The case demonstrates a key issue regarding who pays for what, and what are the benefits that will return to the city's inhabitants for the liabilities they are taking on. In other words what is the value of public space.

Similar debates are seen in London where, as homegrown funding for development has become scarcer in the austerity years, footloose international money has flooded in to fill the gap (Pitcher 2013). This is shaping many of the largest development projects in the city, including three new Westfield shopping centres (built since 2008) and many new

$\overline{9}$ http://www.byoghavn.dk/english.aspx high-density and often high-rise housing and office developments such as around Battersea Power Station. In such places, arguments rage around whether associated 'private' public spaces are too commercial, corporate, securitized, sanitized and exclusionary in feel, and therefore, not really public at all, with some arguing that the austerity years have seen a gradual escalation of such privatisation processes (Garrett 2015). In reality the resulting privately owned and managed public spaces continue to be as varied (in experiential terms) as their purely public and pseudo-public counterparts (Carmona and Wunderlich 2012), and, in common with the other cities, new privately managed public spaces are always shaped by a negotiation between commercial interests and regulatory policies and practices.

\section{Valuing the temporary and exploratory}

Arguably, debates relating to the privatisation of public space are so hotly pursued precisely because such interventions, for good or ill, are so permanent. Yet increasingly both public authorities and private developers are interested in temporary interventions that bring sites into socially beneficial and/or profitable use whilst they are waiting for development to start or for the economy recover (Ferreri 2015). In London, such 'meanwhile' uses are also seen as means to shape perceptions of the emerging place during the development process, for example, the swimming pond and skip garden that featured amongst the programme of temporary spaces animating yet to be developed parts of the huge Kings Cross redevelopment. Reflecting on this move to the temporary, Tonkiss (2013, p. 315) warns: "As useful as meanwhile uses can be, it is important to note how quickly the pop-up can become the tear-down, and the fine margin that at times separate the pioneer use from the urban land-grab, or the creative incubator from the developer demonstration project". But Kamvasinou (2017, p. 205) has argued that in challenging times, these sorts of interventions "enable new types of creative conversations to happen between parties traditionally considered in opposition" and beyond the shortterm impact of the meanwhile use itself can and do lead to better development outcomes over the long-term. In London temporary interventions have been used to encourage: new ways of using the city, such as traffic-free days on Regent's Street; new ways of seeing the city, including the sea of ceramic poppies that slowly grew at the Tower of London throughout 2014; new revenue opportunities, through the more intensive use of underutilised spaces such as car parks for farmers markets at the weekend; or for the testing out of new ideas (Fig. 7).

In Copenhagen, many private development projects came to an abrupt halt in 2009 and landowners had to seek alternative strategies to make their sites profitable. The Carlsberg City project, for example, has been transforming the 


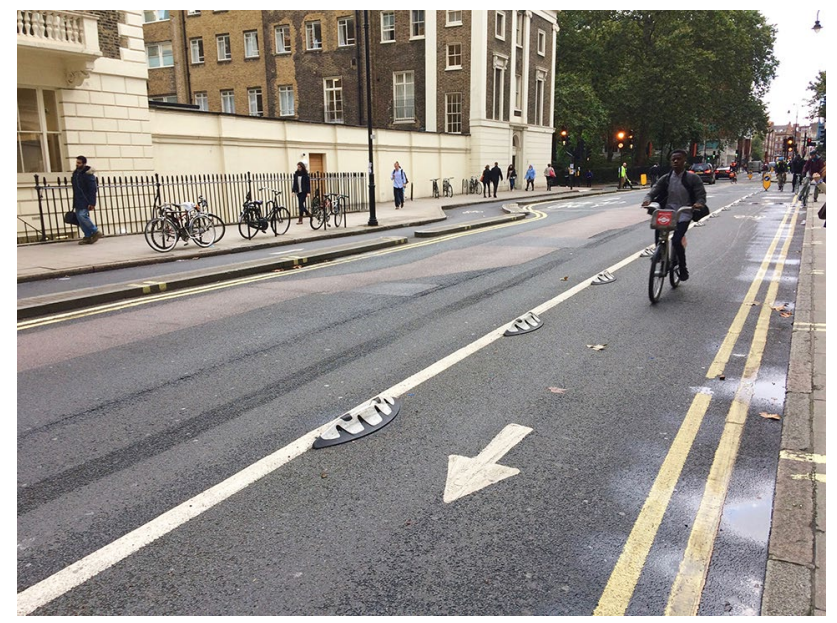

Fig. 7 Exploratory cycleway layouts (to the right of the image) in London's Bloomsbury, implemented at minimal cost prior to more permanent investments (to the left of the image) being made (Matthew Carmona)

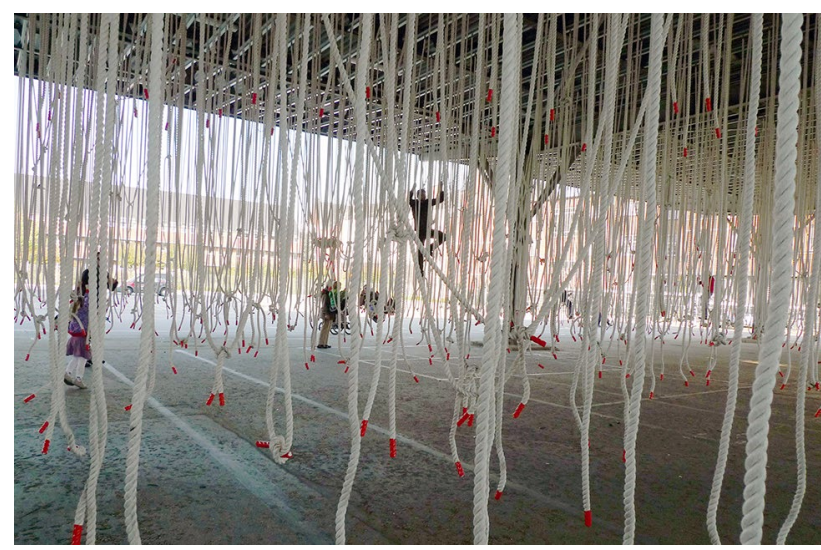

Fig. 8 In the Rope Forest, an open space underneath a large roof construction was filled with gymnastic ropes (Anne Wagner)

site of the former Carlsberg breweries into a mixed urban neighbourhood since 2006, but following the collapse of the housing market in 2009 alternative strategies to activate and 'brand' the area were introduced through a new temporary public space strategy. The public initiative Kickstart København (2010, p. 11) supported the initiative financially with the intention "to create life and activity for the residents in the area until the construction of a new city district" (Fig. 8). The resulting spaces became very popular and were promoted for their experimental approach to urban design (Hausenberg et al. 2011). Later, independently funded activities moved into the area including a climbing obstacle course, a container city flea market, a beach bar, and a range of cultural institutions; all helping to give rise to a distinct Carlsberg culture. Once the market took off again and development activities kicked off, most of the temporary projects

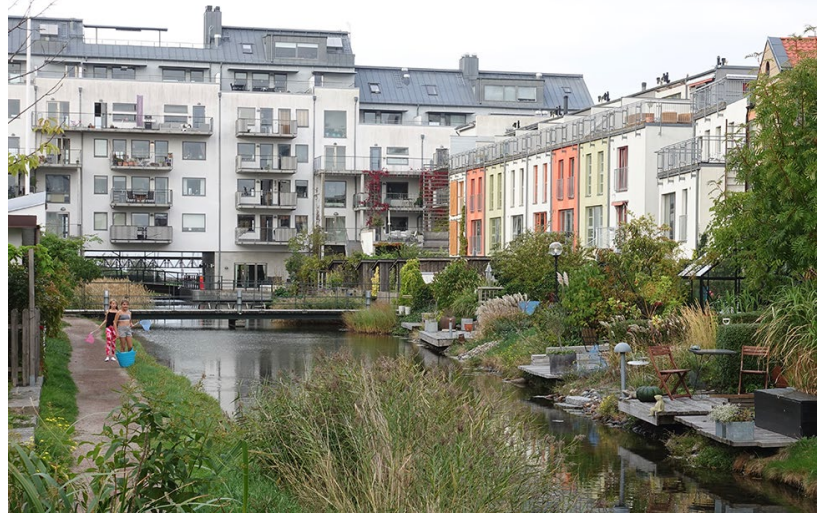

Fig. 9 Western Habour, with its carefully designed public (and private) spaces (Matthew Carmona)

disappeared to the regret of many local citizens, leading to public debate over the value and objectives of temporary projects for urban development.

\section{Cost, up for negotiation}

The Carlsberg case raises a further key issue, if public space projects help to 'make the place', either permanently or temporarily, and thereby add to the profitability of private development projects, who should pay for them? This issue is grappled with across the cities including in Malmö where the municipality has a right under public law to require property owners to pay a street compensation cost; in other words a contribution to any improvement to streets and other common land, as long as the cost is 'reasonable' as determined through negotiation. Following the sale of assets, the municipality was able to cover infrastructure costs in the Western Harbour prior to the financial crisis; believed at the time to be a necessary precondition for developers to invest in the area. Developers, however, subsequently found a ready market for their products and owners have also earned good money when within two years the price of their flats doubled ${ }^{10}$ (Fig. 9). Now, with the municipality in debt at a time of population growth, adequate private contributions to public space are becoming ever more necessary and an investigation was launched in 2018 with the aim of clarifying the proper basis for negotiations on public contributions towards large development projects. ${ }^{11}$

Norwegian planning legislation enables a strong formal role for the municipalities but private developers also have substantial power through their ability to share in the costs of public spaces (Nordahl 2015). These types of partnerships

\footnotetext{
$\overline{10}$ interview, Economy Director, City of Malmö.

11 interview, Manager Budgetary Control, City of Malmö.
} 
are regulated by development agreements under public law which allows municipalities to create juridical binding planning provisions which zone areas as public space. Under these provisions the Oslo Municipal Plan for Public Space and Meeting Places (City of Oslo 2009) includes a binding requirement that privately developed projects exceeding $20,000 \mathrm{~m}^{2}$ should reserve a minimum of $5 \%$ land for public space. Some of the resulting spaces end up being privately owned and managed whilst others are managed by the municipality.

Negotiation is also the key in London, with major development subject to bespoke planning agreements. Typically, such negotiations encompass a wide range of public goods from schools to roads, and streets to social infrastructure. In such complex negotiations, there is a danger that public space issues are given inadequate attention and that spaces are then either sub-standard when completed or long-term rights and responsibilities are inadequately resolved. Carmona (2014b) has argued that there is need for the Mayor to adopt a clear and simple charter of public space rights and responsibilities to cover the whole city and this idea was picked up in the 2017 draft London Plan which promises that the Mayor will bring forward a Public London Charter (Mayor of London 2017: Policy D7). As things stand, however, each of the 33 boroughs (and the Mayor) do their own thing and in these negotiations (particularly in the immediate post-crisis years) developers are in a strong position.

\section{Infrastructure as place making}

The Malmö Live case encapsulates a further key trend, of delivering public space projects as a by-product of investments in local or strategic infrastructure. In this case the co-location of the concert hall and the congress centre was promoted from the start. The justification for this, however, changed over time, from one focussed on saving the municipality money (Malmö stad 2008, p. 8) to one focussed on natural synergies and the creation of new jobs and economic growth (Malmö stad 2015b, pp. 6-7). The emergence of the foyer or Urban Common represented a natural development of this as both facilities would feed into it and help to further the new knowledge-based vision for the city. In Copenhagen, public space redevelopment is increasingly being financed through investments in local infrastructure directly effecting public space. For example, up to 2033, the city will invest 3.8 billion Danish Crowns in cloudburst management (City of Copenhagen 2012b).

In London, although public expenditure has been dramatically cut back during the austerity years, expenditure on new public space projects has faired relatively well care of its association with expenditure on the 2012 Olympic Games, and latterly on public transport. Across England, whilst funding to local government reduced on average by $25 \%$



Fig. 10 The Queen Elizabeth Olympic Park, Stratford-post games (Matthew Carmona)

between 2010 and 2014 (NAO 2014) new transport infrastructure spending in London has been shielded by the need to address London's growth and an historic backlog in infrastructure investment. During this period also, Government has been on a journey. In the past, it viewed such infrastructure as costly bits of technical kit to be delivered at minimum cost to the public purse and with little concern for the local impact. Only now is a realisation dawning that such investments are pieces of city building with huge place-making potential well beyond the infrastructure itself (Savills 2014, pp. 6-7). The commitment to carefully design a new public realm around the 40 new Crossrail (Elizabeth Line) stations soon to be opening across the city represents the clearest demonstration of this thinking, whilst the range of new and enhanced spaces associated with the Olympics have been transformational in parts of East London (Fig. 10), demonstrating the potential of infrastructure-led public space.

\section{Use}

\section{From utilitarian to leisure and specialist uses}

Whilst the gradual re-balancing of space (already refereed to) in favour of pedestrians and cyclists is likely to be a long-term trend across the four cities, other pressures are also acting to change how public spaces are used. Particularly pervasive is the impact of the internet on almost every aspect of life, and most particularly on shopping habits and on the consequential viability of traditional mixed (shopping) streets (Carmona 2015). In London, one consequence is that many local shopping streets are slowly moving from a utilitarian retail or service (e.g. banking) function for everyday needs to a leisure and more specialist range of functions, 
including catering to the tastes of new immigrants to the city (Wrigley and Lambiri 2014, p. 19). Coffee shops are spreading like wildfire and pop-up coffee venders are appearing on busy street corners leading some to wonder when 'peak coffee' will be reached (Haughton 2015). The changes have increased in pace since the crash of 2008 when spending power fell dramatically and increasingly spend moved online (ONS 2016). All this is changing both why people visit key public spaces in the city and how they function.

In Oslo, there has been a focus on strengthening traditional shopping streets by upgrading the streets from transport routes to public spaces. A special project, Bylivsprosjektet (Urban public life), has been initiated with the aim of securing a vibrant urban life in the central area when the car-free zone is established. However, in newer areas of the city this has been more difficult as retail is concentrated in internal privately owned and managed shopping centres. Storo storsenter in Nydalen, for example, is a mixed office and residential area with a high student population, but outside of office hours its streets are quickly deserted with the exception of areas along the river which are part of the blue/ green network and popular for walking, cycling and jogging (Selvig 2015). At the same time numbers of cafés have multiplied and pavement areas have increasingly been taken over for outdoor sitting, giving life and vitality to many traditional streets. These trends are particularly evident in the recently gentrified areas of the city such as Grünerløkka in the inner eastern part of Oslo.

In Copenhagen, the move towards better and more heavily utilised public spaces continued throughout the austerity years and today Copenhagen's public squares, parks, outdoor cafes streets and pathways are packed with people on warm days. This is confirmed by the urban life data collected between 2010 and 2015 that demonstrates an increase in both facilities and the use of public spaces (City of Copenhagen 2015b). For instance, outdoor seating permits increased by more than $100 \%$ in inner and central neighbourhoods during this time whilst the number of events increased between 34 and $80 \%$ depending on the district. All this is seen by the city as an enhancement to general quality of urban life. The published Urban Life Account follows local improvement projects from before to after completion and draws the broad conclusion that developing attractive public spaces, and creating more and better possibilities for leisure activities and seating increases the number of people using public spaces (City of Copenhagen 2015b).

\section{A tale of two cities (and different populations)}

If, for some users, public spaces have become places of leisure, for others this is not the case. The goal of Malmö Live, for example, was to create "a meeting place where people with different experiences, knowledge and ideas can meet in cultural diversity" (Malmö stad 2008, p. 6) and so far the response from the inhabitants in Malmö has been overwhelming (Malmö Live Konserthus 2016). Observational studies of the foyer reveal that this space is in constant use and is acting as a new meeting place within the city. Users, however, are mostly young and seemingly well educated who use the comfortable sofas with its free wi-fi as a place to work. In this sense, the space is not working as an Urban Common (as was originally intended). Instead, the exclusive feeling of the interior and constant surveillance by staff act to keep large groups of inhabitants outside. The reality is that this space was not primarily designed for ordinary citizens but instead for the creative classes who "want to live in cities that can offer a rich cultural life, a lively atmosphere and a tolerant milieu" (Malmö stadsbyggnadskontor 2008, p. 8). In this narrow way, it is clearly successful, although the question remains, should public money be invested in spaces that promote economic growth if the benefits do not trickle down to the poor. As the Mayor has admitted, the huge investment has meant that other projects have been postponed (Sydsvenskan 2015).

London, as a global city, has long been considered a magnet for the sorts of creative classes that Malmö is focussed on attracting. Arguments have raged about the gentrification impacts of these populations and about provision for those at the opposite end of the social spectrum. The differential impact can be seen in the state of the city's traditional retail streets. Whilst some (in affluent areas) thrive, others (in less affluent areas or on busy trafficked roads) have been struggling to adapt to the new realities of the online marketplace, large multi-national discount retailers, and gentrified populations seeking the different (leisure) experience already discussed, and who are prepared to travel. The fate of many of London's traditional street markets is a strong bell-weather of this, and have either declined and all but disappeared during the austerity years (Jarvis 2015) or have had to adapt and find a new income as part of the leisure economy. The contrasting fates of Borough and Petticoat Lane markets, both on the edges of the City of London, but serving very different populations has been tracked for over 10 years by Kim (2017). This work reveals the stark story of adapt and survive or fail to adapt and go under.

The rise in visible homelessness has also been dramatic, with changes in migration patterns across Europe, austerityled reductions in benefits entitlements in the UK, and cuts in services for the homeless and those with mental health difficulties, all leading to significant rises in rough sleepers (Crisis 2016) (Fig. 11). Associated rises in begging and arrests (up 90\% according to some estimates-Watts 2014) are also contributing to stark and very public contrasts between haves and have-nots.

In Oslo, the presence of beggars is a relatively new phenomenon, but in recent years begging, mainly by a 


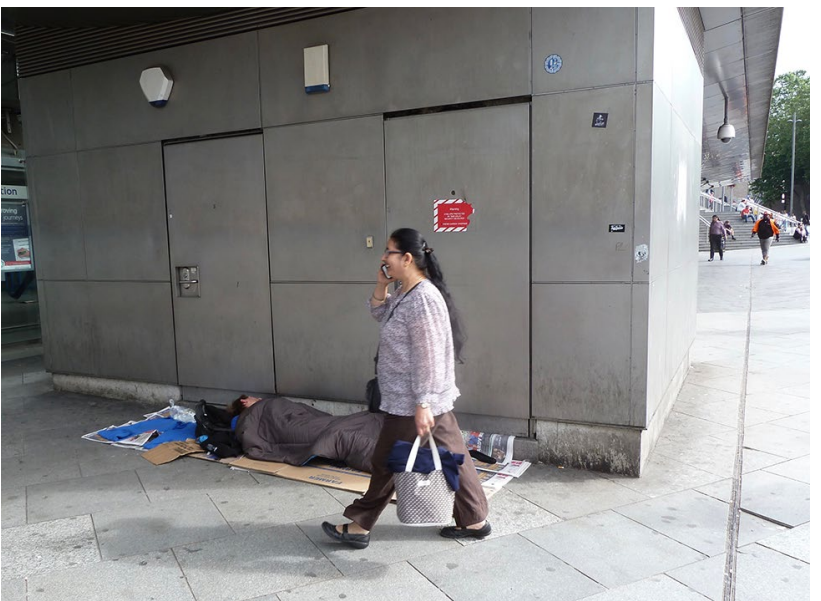

Fig. 11 The rise in rough sleepers represents a direct and highly visible impact of austerity (Matthew Carmona)

sub-section of the Rumanian community, has become far more common. This has spurred a public debate about rights in urban public spaces, and what types of use are or are not acceptable. Whilst some politicians on the city council have argued for forbidding begging in public spaces, many others, and most citizens, have come out against this view.

\section{Reasserting democratic space}

Since 2008, demonstrations against austerity politics in Europe have reconfirmed the critical democratic role of public space. In London, protest and demonstration remains a regular occurrence, with the Occupy and Stop the War camps of 2011/12 forcefully re-asserting the historic role of public space for demonstration and political purposes (Tonkiss 2013 , p. 315). Eventually, the legal limits of such protests were tested in the courts and the camps began to disappear as legislation effecting Parliament Square was redefined ${ }^{12}$ and elsewhere rights to protest and of association under the 1998 Human Rights Act were shown not to extend to the right to occupation. Consequently, the early light touch policing and tolerance of such activities, which were largely peaceful, has been replaced with more active and rapid intervention as and when deemed necessary. By contrast, the rights and wrongs of the 2011 riots which affected large parts of London in a far more dramatic and disturbing manner remain contested. Under Mayor Boris Johnson they nevertheless helped to drive significant public funds in the direction of the most affected areas, much of which was focussed on improvements to the physical built environment of the spaces that had been targeted.

$\overline{12}$ via the Policy Reform and Social Responsibility Act 2011.

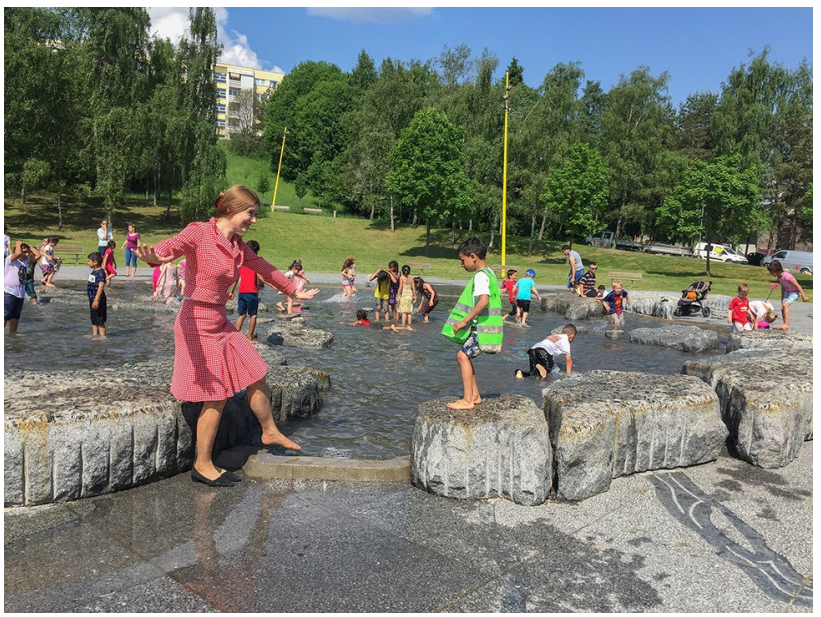

Fig. 12 Verdensparken (World park), Furuset, an upgrading of postwar green space to create a park attractive to different uses and the area's multi-cultural inhabitants, all based on an exemplary participatory design process (Kommunal - og Moderniserings Departementet, Ministry of Modernization and Local Democracy)

In Copenhagen, there is an attempt to strike a balance between spaces for all and spaces for more specific uses, as well as the need to include marginalised groups in the public space programme. The approach deliberately recognises the multifunctionality of space and that encounters with 'the other' is a quality in itself. Thus, the city promotes public spaces that not only engage the populace at large but also allocate room for more specific uses. Funding bodies such as Lokale og Anlægsfonden support public space designs that promote more active everyday life through facilities for football, play, fitness, basketball, skating, parkour and other activities. By way of contrast, there are instances of organised citizen groups that have been allowed to adopt sections of public spaces as semi-private urban gardens, as has occurred in Byhaven 2200 in the Nørrebro Park, ${ }^{13}$ whilst in Enghave Plads a group of heavy drinkers were invited to design their own public space in collaboration with the artist Kenneth Balfelt (Socialministeriet 2010, pp. 44-55).

In Oslo, such an inclusive view of public space was firmly established in the legally binding Municipal Plan for Public Spaces and Meeting-Places (City of Oslo 2009). In the plan, the focus is on strengthening local attachment, place identity and social life in spaces that are important to local communities with a special emphasis on groups with low mobility. ${ }^{14}$ As the Oslo Head of parks puts it: "Earlier people promenaded in the park, now people do their exercise, walk their dog, have picnics, and sunbathe. People find

\footnotetext{
13 http://www.byhaven2200.dk/

14 https://www.flickr.com/photos/kmdep/26911900553/in/album -72157668977398132/
} 


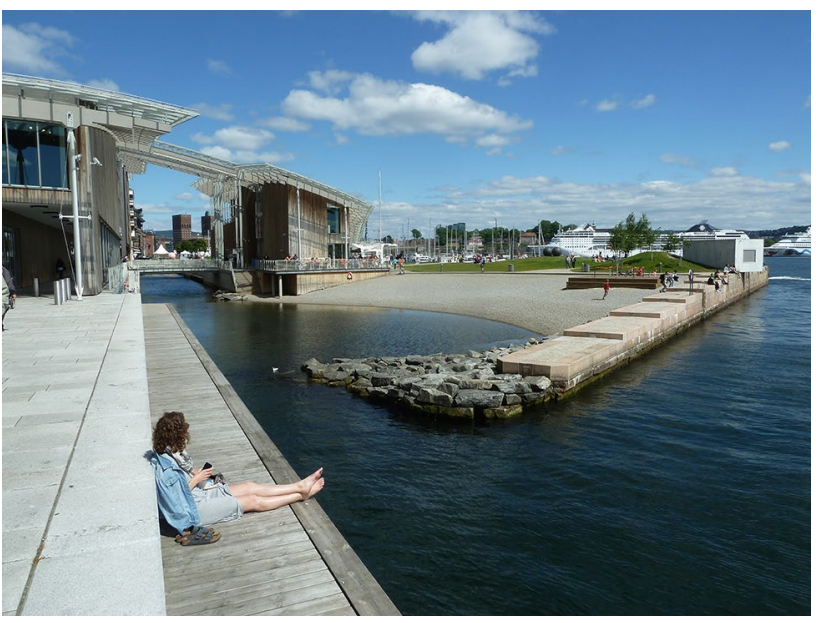

Fig. 13 Tjuvholmen, on Oslo's western harbour (Matthew Carmona)

their favourite and use it like their own garden. The park no longer belongs to the municipality, it belongs to you and me. And we use it very differently. We might well say that the park has been democratized" (City of Oslo 2016) (Fig. 12).

\section{Management}

\section{Caring for the everyday physical fabric (public and private)}

In London (unlike Copenhagen), the first cuts to be made when the public finances got tight were to the budgets for managing the city's public spaces; cuts that have fallen disproportionately on those living in the most deprived areas (Hastings et al. 2015, p. 9). Whilst at first this largely went unnoticed, the impact is cumulative as revealed in official statistics relating to the dramatic increase in potholes and associated accidents on the city's streets (Williams 2016). As decline in the public physical fabric sets in, so potentially does the closely associated wellbeing of citizens who now experience an uglier and seemingly less loved environment, leading to a stronger desire amongst commercial interests to manage new spaces themselves (London Assembly 2011, p. 22).

Underpinning some of these trends, across Europe, are the New public management approaches as applied to public spaces, that are so strongly associated with the politics and practices of neo-liberalism (De Magalhães and Carmona 2007). In Oslo, the management of public spaces and parks has been progressively outsourced. When first mooted, this raised concerns because of the unique competences that already existed in the public sector. However, with the exception of complaints relating to the prosaic task of clearing snow and spreading grit on icy pavements, the policy has been implemented without controversy. The city also has an increasing range of public activities occurring on private land and the private management of publicly accessible space has occurred more often. A study of management practices in Tjuvholmen (Fig. 13), for example, shows a very strict management regime, where graffiti and litter is quickly removed, repairs are done almost immediately and green areas are very well kept (Murphy 2017), although there have been tensions. In this new and exclusive neighbourhood on the Oslo waterfront, the public have access to facilities for swimming in the fjord which is popular on hot summer days. In 2015, however, complaints from residents led to restrictions being placed on swimming after $8 \mathrm{pm}$. Following a local newspaper campaign a re-think was forced and a relaxation of the rules occurred which are now only enforced after $11 \mathrm{pm}$.

Similar debates about access to and rights over privately owned public spaces and the tendency for management regimes to be over officious in their enforcement of privately defined management codes also regularly feature in the London and national press. Concern that "In an age of austerity ... Budget pressures on local authorities are increasingly leaving the management of public space in the hands of developers" (London Assembly 2011, p. 9), led in 2011 to an enquiry by the London Assembly into such practices. Whilst the inquiry concluded that greater attention should be given in policy to ensuring a consistent consideration of management issues at the time planning permission is given, it also argued that "private ownership or management of public space is not, in itself, a cause for concern" (London Assembly 2011, p. 11).

\section{Space as empowerment}

In Copenhagen, significant efforts have been made to engage citizens in the creation of new public spaces, including Superkilen (see Fig. 4). This, like many public space projects was part of a larger area renewal effort, co-financed by national government and the local municipality, although increasingly with contributions from private foundations. The neighbourhood-based five-year area renewal initiatives develop vision plans and public space strategies one neighbourhood at a time and in close dialogue with local residents, neighbourhood associations and other stakeholders. In the southern harbour, for example, temporary projects have been deployed as a way to test and promote new ideas for public spaces as a tool to include residents in their design and making and as a method to foster local empowerment and nurture new collaborative models for their management 




Fig. 14 The Line art walk, from the $\mathrm{O} 2$ to the Queen Elizabeth Olympic Park, here Damien Hirst's Sensation acting as an unintended plaything (Matthew Carmona)

(City of Copenhagen 2015c). The political ambition of the Community Copenhagen strategy aims to promote greater local engagement and democratic processes but also to achieve increased citizen responsibility for public spaces. While not expressed in the strategy, there is also an ambition to reduce the cost of maintenance by encouraging more citizen-driven caretaking.

In the UK, a second narrative of community empowerment and localism has accompanied that of austerity. Some see this as a cynical attempt to paper over the cracks left by cuts in public services (Hambleton 2011) but community and local action has certainly flourished in some of the gaps. Notably this has included significant numbers of community groups now involved in green space management across London (Bawden 2016), such as the Rocky Park community garden in Bethnal Green where volunteers have transformed an unloved hang-out into a productive space for flowers and vegetables. Elsewhere, crowd funding is being used to innovate new projects as diverse as The Line art walk along the River Lee (Fig. 14) and the proposed Coal Line urban park utilising disused coal sidings in Peckham. At a larger scale, the voluntary '20's plenty for us' campaign is encouraging communities to demand slower speed limits on residential roads, and by 2017 had convinced nine of London's 33 boroughs to adopt $20 \mathrm{mph}$ speed limits across their entire local roads network. ${ }^{15}$

\footnotetext{
$\overline{15}$ http://www.20splenty.org/20_s_plenty_for_london_update_sep_16
}

\section{Management by cappuccino (sponsorship and advertising)}

Beyond enlisting the direct help of citizens, tighter budgets for the management of public spaces have left local authorities increasingly looking to external sources of income to help fill some of the gaps, notably by exploiting commercialisation opportunities. Although some hysterical reports have raised the potential for local authorities to close and sell off facilities such as parks, or otherwise give them over to private interests, such as companies in the personal fitness industry (BBC News 2015), there is no incidence of this actually happening beyond a single case of the tree tops in Battersea Park being rented out for adventure climbing (Plimmer 2016). Instead, commercialisation activities are typically small scale and include renting pitches to the sorts of mobile coffee venders already referred to. They also encompass sizable and longer-term outdoor advertising contracts as councils seek to cross-fund the management of public space through selling advertising rights on public buildings, bus shelters, and on free-standing hoardings. ${ }^{16}$

From 2010, the 'Boris Bike' cycle rental scheme (named after the former Mayor) brought private sponsorship more visibly and ubiquitously into the public realm with sponsorship initially by Barclays and latterly Santander Banks. ${ }^{17}$ This mirrors schemes elsewhere including the Oslo City Bike scheme sponsored by Clear Channel who fund city bike spaces in exchange for pitches for advertising hoardings and for advertising on the bikes themselves. ${ }^{18}$ Likewise advertising on bus shelters in Oslo helps to provide funding for the provision and maintenance of the shelters, whilst, more ambitiously, the whole Malmö Live project was only finally delivered courtesy of cross-funding and sponsorship arrangements that were agreed at the last minute between the developer, Skanska, and the city (Malmö stad 2015b, p. 13). This has delivered 4 million SEK annually for 5 years from the opening, and $12 \%$ of the income (1.2-1.8 million SEK a year) from restaurant sales across the facility for 20 years (Skanska 2011).

\section{The security question}

A final management concern relates to the question of security that has long featured as a consideration

\footnotetext{
16 http://www.outsmart.org.uk/news/clear-channel-wins-tower-hamle ts-bus-shelter-advertising-contract.

17 What the future is for these bikes is unclear after the launch in 2017 of the first dockless bike hire scheme, with, by the summer of 2018: four companies competing for the business in London, huge plans for expansion of this fleet, and prices that significantly undercut their docked counterparts.

18 https://oslobysykkel.no/en/about.
} 


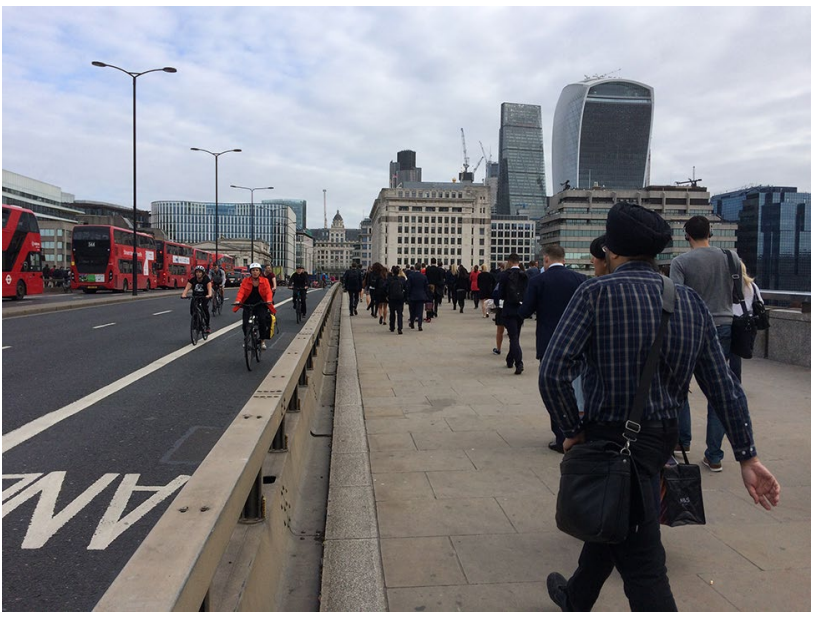

Fig. 15 Barriers installed on some Thames bridges following the London terror attacks of 2017 (Matthew Carmona)

in London with its history of IRA attacks from 1971 through to 2001, and radical Islamist attacks starting not long afterwards through to 2017. Shootings in 2015 in Copenhagen had similar ideological roots, whilst the 2011 bombing of government offices in Oslo and subsequent massacre on Utøya island had very different far right roots. Given these attacks and numerous other smaller or thwarted attacks in the four cities covered in this paper, it is surprising that security measures are, in general, so absent.

In London, the installation of security measures (physical barriers) in a few high-profile public spaces has been the subject of much debate with a degree of target hardening around prominent buildings such as the Houses of Parliament and (recently) on bridges over the River Thames (Fig. 15); although there remains a determination that such issues will not impact on access to the city's key iconic venues (Syal and Asthana 2017). In Oslo, the need to express sorrow following the 2011 attacks resulted in Rosetoget when 200,000 people gathered outside Oslo Town Hall with flowers. The resulting interrogation of security arrangements led to accusations that government had been negligent given the ease with which it was possible to drive up to the entrance of a government building with a car bomb (NOU 2012, p. 14). Careful consideration is now being given to security issues and how that balances with democratic access in relation to the public spaces being proposed for the new government quarter (Regjeringskvartalet) proposed in Oslo. Unfortunately, on this most confounding of management issues, the 2017 vehicle attacks in London demonstrated how profoundly difficult it is to prevent such attacks without impacting on the democratic nature of European cities.

\section{Conclusion}

\section{Evolving power relationships}

Terry Farrell (2017, p. 137) advances the thesis that "there is only one thing worse for urban design than a recession, and that is a boom" with the inevitable emergence of cashrich developers wanting to make a fast buck whilst the going is good. Clearly there is a contradiction here. Whilst recessions slow things down and offer greater scope for the careful consideration of projects, it is also far harder to get projects built, particularly if, as has been the case since 2008 , larger economic challenges are matched by cuts in public funding. In reality it was only the start of the decade discussed in this paper that actually saw technical recession in the four cities that have been discussed, after which the private sector continued to steam ahead with a vengeance whilst resources were being systematically removed from the public sector.

Across the cities, the age of austerity has seen subtle changes in the power relationships of stakeholders, and this has occurred within a context of a diversification in the design, development, use and management practices relating to the shaping of public spaces:

- In London, the austerity years do not seem to have substantially altered the balance between players responsible for or affected by public space, Roberts (2017) goes so far as to suggest that, for London, austerity simply represented "business as usual". Public space has always been diverse in its ownership, management and use, and continues to be so, although the period has seen a renewed emphasis on very large projects of different types. Typically, these have been driven forward by single developers who increasingly retain ownership, either themselves or via long-term management organisations, of key spaces. Whilst this might be viewed as a move to more privately owned and managed spaces, in reality these sites were never in public ownership in the first place, or if they were, were often badly degraded and used only by those who had little choice but to do so.

- In Copenhagen, the contemporary focus on public space has a longer pedigree and is arguably more ingrained than the other cities, so whilst the city was more severely affected by the economic crisis than some, urban development, and specifically the emphasis on creating a liveable city with high quality public spaces at its heart was seen as part of the solution, rather than as a luxury to be abandoned because public finances were tight. Indeed, this represented the key means through which the city increasingly represented 
itself globally, evolving its approach with a greater emphasis on bottom-up initiative and engagement, and utilising public space investments to support the city's larger quality of life and environmental aspirations. Like London, there has been a subtle move away from the state as the direct provider of public space, towards more complex collaborative structures where local actors-public and private-join forces to fund and facilitate public space programmes to meet mutual goals such as the renovation of school grounds that double as public spaces, provision of bicycle paths that are developed in tandem with urban green areas, and storm water management projects that are used as a vehicle for improving public spaces.

- Sometimes, as has been the case in Malmö, these more diffuse ways of working lead to compromise and occasionally conflict. The lack of transparency underpinning the financial case behind Malmö Live, for example, has raised concerns about in whose interest the project was realised. For years to come Malmö will be burdened with the debt associated with the construction of Malmö Live, money that is no longer available for the massive investments the city needs to make in its social infrastructure. In this sense Malmö Live could be seen as part of a major shift "from a more collective to a more individualised form of public benefits" (Lehrer and Laidley 2008, p. 799). Like London and Copenhagen, increasingly the city is looking to public-private cooperation to achieve its aspirations, and this firmly links the creation of successful public space to the larger economic interests and aspirations of both the city and those same private parties.

- In Oslo, there has been an increasing tendency for the city to require a financial contribution from private developers for providing new public spaces in development projects leading to a greater capacity of the city to both create and manage high quality public spaces. While this gives private actors greater power in the design, development and management of urban public spaces, the city has become increasingly conscious of its role in steering these processes to ensure that outcomes are optimised. As in the other cities this involves a conceptual development of this role as the city has become increasingly conscious about the social, sustainable, health and economic benefits of a high-quality public realm. By refining the design governance tools at their disposal-the various plans, juridical binding planning provisions, and co-financing models - the city has been able to successfully negotiate these shifts in power.

The opportunities and challenges created by a rapidly changing economic and social climate seems to have led to a period of rapid innovation across the four cities and across the public spaces remit as represented in the different dimensions of the place-shaping continuum used to structure this paper. Whether, ultimately this will lead to better or worse, more or less democratic public space is yet to be seen, the evidence collected here suggests that even single cities can exhibit many, sometimes quite contradictory practices and outcomes.

\section{The multiple evolving spaces of the austerity era}

Put positively, this might be framed as a move from a 'placemaking' to a 'place-shaping' position, where public space investment is sometimes used to create new spaces, but more often shapes existing ones in a manner that attempts to deliver on an ever more challenging array of public policy goals: health, citizen engagement, economic competitiveness, social and environmental resilience, safety, and so forth.

Yet even in cities so clearly in the public space advocate mode as the four studied, public spaces need to be nurtured and protected against pressures (if and where they exist) to undermine the key qualities that give them their essential sense of 'publicness'. In the four cities these relate variously to such issues as transparency in the provision, rights and responsibilities associated with space; addressing the needs of haves and have-nots simultaneously; finding new innovative means to breathe life into some of the most challenging and relentlessly sub-standard city spaces such as declining mixed retail streets; and the need to balance democratic rights and inclusiveness with threats from extremism, unfettered economic exploitation (where it exists) and the impact of cuts (where they persist) in the prosaic but vital stewardship of public spaces.

Some of the forms of public spaces (for good or ill) that have multiplied as a result of the trends discussed in the paper include:

- Spaces of expectation-the everyday multi-functional spaces, charged with ever-greater expectation and responsibility

- Spaces of the private/public sphere—shaped by private ownership and management

- Spaces of spectacle_establishing the place and 'selling' the city

- Spaces of respite-offering relief from the increasingly intensity of a densified city

- Spaces of infrastructure-repurposing redundant infrastructure or piggy-backing on infrastructure investment

- Spaces of diversion-leisure spaces for the affluent and the 'creative classes'

- Spaces of income generation-featuring sponsorship and/or other commercial funding opportunities 
- Spaces of security—hardened against threats and atrocities

- Spaces of the ephemeral city-between one phase and the next, meanwhile

- Spaces of community control-where communities have taken over management responsibility

- Spaces of occupation-occupied for demonstration and political purpose

- Spaces of disadvantage - taking root in the cracks of the city, in amongst the affluence

- Spaces of decline-suffering the effects of structural change and disinvestment

All these types of space exist, even in single cities, and sometimes multiple types exists in the same space: the space of spectacle as locus for the homeless to beg; the creative classes diverted by the excitement of the ephemeral; or shoppers in everyday space (of expectation or decline) negotiating the array of ever more prominent security measures.

Over this the neo-liberal project persists, sometimes more (e.g. London) sometimes less (e.g. Copenhagen) obvious in its expression, and always of a hybrid form; neo-liberal within a social-democratic setting. It is interesting then that within this context, the evidence gathered suggests that (in toto) the direction of travel, if not every outcome, is more positive than negative. Despite the financial pressures, in these four cites the commitment to public space and its critical social role in society has been maintained. In this respect, the crisis has not gone to waste.

Acknowledgements The authors would like to acknowledge funding from the Norwegian Research Council and from the Economic and Social Research Council in the UK who funded the original research on which the analytical framework for this paper is based.

Open Access This article is distributed under the terms of the Creative Commons Attribution 4.0 International License (http://creativeco mmons.org/licenses/by/4.0/), which permits unrestricted use, distribution, and reproduction in any medium, provided you give appropriate credit to the original author(s) and the source, provide a link to the Creative Commons license, and indicate if changes were made.

\section{References}

Adams, S. 2010. Prince of Wales's emotional Chelsea Barracks letter revealed, The Telegraph, 24th June, http://www.telegraph.co.uk/ culture/culturenews/7850091/Prince-of-Waless-emotional-Chels ea-Barracks-letter-revealed.html.

Amin, A. 2006. Collective Culture and Urban Public Space, http:// www.publicspace.org/en/text-library/eng/b003-collective-cultu re-and-urban-public-space.

Architects, Gehl. 2004. Towards a Fine City for People, Public Spaces and Public Life - London 2004. Copenhagen: Gehl Architects.

Andersson, R., A. Bråmå, and J. Hogdal. 2007. Segregationens dynamik och planeringens möjligheter [Dynamics of segregation and the possibilities of planning]. Malmö: Malmö stad.
Bawden, T. 2016. Britain's public parks threatened with privatisation as cuts stretch council budgets, The Independent, 27th June, http://www.independent.co.uk/news/uk/home-news/britains-publi c-parks-threatened-with-privatisation-as-cuts-stretch-councilbudgets-10349408.html.

BBC News. 2015. London's parks 'could become inaccessible to the public', 21st June, http://www.bbc.co.uk/news/uk-england-londo n-33205239.

Bergsli, H. 2015. Urban attractiveness and competitive policies in Oslo and Marseille, unpublished $\mathrm{PhD}$ thesis, Institute of Sociology and Human Geography, Oslo, University of Oslo.

Biddulph, M. 2011. Urban design, regeneration and the entrepreneurial city. Progress in Planning 76: 63-103.

Bisgaard, H. 2010. Københavns genrejsning 1990-2010 (The reconstruction of Copenhagen 1990-2010). Bogværket.

Boligvekstutvalget. 2016. Økt boligvekst i Oslo. Rapport fra boligvekstutvalget, November 26.

Bone, J. 2012. The Neoliberal Phoenix: The Big Society or Business as Usual. Sociological Research Online, 17(2) http://www.socre sonline.org.uk/17/2/16.html.

Bramall, R. 2013. The Cultural Politics of Austerity. Basingstoke: Palgrave MacMillan.

Carmona, M. 2012. The London Way: The Politics of London's Strategic Design. Architectural Design 82 (1): 36-43.

Carmona, M. 2014a. The Place-shaping Continuum: A Theory of Urban Design Process. Journal of Urban Design 19 (1): 2-36.

Carmona, M. 2014b. Neo-liberal public space, in London (and beyond), Urban Design Matters January, https://matthew-carmo na.com/2014/01/12/neo-liberal-public-space-in-london-andbeyond/.

Carmona, M. 2015. London's Local High Streets: The Problems, Potential and Complexities of Mixed Street Corridors. Progress in Planning 100: 1-84.

Carmona, M., and F. Wunderlich. 2012. Capital Spaces, The Multiple Complex Spaces of a Global City. Oxford: Routledge.

Cho, I.S., C.K. Heng, and Z. Trivic. 2016. Re-framing Urban Space: Urban Design for Emerging Hybrid and High-Density Conditions. New York: Routledge.

City of Copenhagen. 2006a. Handlingsplan for byrum [Action Plan for Urban Space]. Copenhagen: City of Copenhagen.

City of Copenhagen. 2006. Handlingsplan for byrum [Action plan for urban space], Copenhagen, City of Copenhagen. Available at: kk.sites.itera.dk/apps/kk_pub2/pdf/107_Byrumshandlingsplan.pdf.

City of Copenhagen. 2009. A metropolis for people: Visions and goals for urban life in Copenhagen 2015, http://kk.sites.itera .dk/apps/kk_pub2/pdf/646_mIr0dQ6Wdu.pdf.

City of Copenhagen. 2012a. Copenhagen Climate Resilient Neighbourhood. Available at: http://www.klimakvarter.dk/wp-conte nt/2013/03/klimakvarter_ENG_low.pdf.

City of Copenhagen. 2012b. The City of Copenhagen Cloudburst Management Plan 2012. Available at: http://en.klimatilpasning .dk/media/665626/cph_-_cloudburst_management_plan.pdf.

City of Copenhagen. 2015a. Fallesskab Kobenhavn: Vision for 2025 [Community Copenhagen: Vision for 2025]. Copenhagen: City of Copenhagen.

City of Copenhagen. 2015b. Urban Life account 2015. Copenhagen: City of Copenhagen.

City of Copenhagen. 2015c. Kvarterplan for områdefornyelse Sydhavnen. Copenhagen: City of Copenhagen.

City of Oslo. 2009. Kommunedelplan for torg og moteplasser [Municipal Thematic Plan for Squares and Meeting-Places in Oslo]. Oslo: City of Oslo.

City of Oslo. 2016. ByplanOslo Parkbyen Oslo: - Velkommen til min demokratiske hage [Park-City Oslo: Welcome to My Democratic Garden]. Oslo: City of Oslo. 
Christodoulou, C., and S. Lada. 2017. Urban Design in the NeoLiberal Era: Reflecting on the Greek Case. Journal of Urban Design 22 (2): 144-146.

Crisis. 2016. The Homelessness Monitor: England 2016, http://www. crisis.org.uk/data/files/publications/Homelessness_Monitor_ England_2016_ExecSummary_v1.pdf.

Dannestam, T. 2009. Stadspolitik i Malmö, politikens meningsskapande och materialitet. Lund: Lunds Universitet.

De Magalhães, C., and M. Carmona. 2007. Innovations in the Management of Public Space, Reshaping and Refocusing Governance. Planning Theory and Practice 7 (3): 289-303.

De Magalhães, C., and M. Carmona. 2009. Dimensions and Models of Contemporary Public Space Management in England. Journal of Environmental Planning and Management 52 (2): 111-129.

Ferreri, M. 2015. The Seductions of Temporary Urbanism. Ephemera 15 (1): 181-191.

Farrell, T. 2017. There is Only One Thing Worse for Urban Design Than a Recession, and That is a Boom. Journal of Urban Design 22 (2): 137-139.

Garrett, B. 2015. The privatisation of cities' public spaces is escalating. It is time to take a stand. The Guardian, 4th August, https:// www.theguardian.com/cities/2014/dec/30/what-i-want-from-ourcities-in-2015-public-spaces-that-are-truly-public-boris-johnsonlondon.

Greater London Authority. 2015. Natural Capital, Investing in a Green Infrastructure for a Future London, Green Infrastructure Task Force Report. London: GLA.

Guttu, J. \& L. Schmidt. 2008. Fortett med vett. Eksempler fra norske byer. Miljøverndep., Husbanken, NIBR.

Hambleton, R. 2011. A Jekyll and Hyde Localism Bill. Town \& Country Planning, January 80: 15-17.

Hanssen, G.S., H. Hofstad, and I.-L. Saglie. 2015. Kompakt byutvikling. Muligheter og utfordringer [Compact city Development, Possibilities and Challenges]. Oslo: Universitetsforlaget AS.

Hastings, A., N. Bailey, G. Bramley, M. Gannon, \& D. Watkins. 2015. The Cost of Cuts: The Impact on Local Government and Poorer Communities, Joseph Rowntree Foundation, https://www.jrf.org. uk/sites/default/files/jrf/migrated/files/Summary-Final.pdf.

Haughton, J. 2015. Have we Reached Peak Coffee'? Eight Stirring facts and Stats. http://www.managers.org.uk/insights/news/2015/ april/have-we-reached-peak-coffee-eight-stirring-facts-and-stats.

Hausenberg, v. Marie Leth Meilvang, Astrid Liest $\varnothing 1$ Henningsen, Stephanie Winther, Lise Røjskjær Pedersen og Nicolai Carlberg. 2011. Midlertidige byrum på Carlsberg. Evaluering http://www. loa-fonden.dk/media/1436/evaluering-af-midlertidige-byrum-paacarlsberg-2011.pdf.

Holgersson, S. 2014. The Rise of Postindustrial Malmö-Investigation of City Crisis Dialectics. Lund: Lund University.

Jarvis, G. 2015. End of the Road for London's Traditional Street Markets? Meet the Last Stallhoder in Hackney's 'Waste'. The Guardian, 17th April, https://www.theguardian.com/cities/2015/apr/17/ decline-london-street-market-hackney-waste.

Jacobs, J. 1961, 1984 edition. The Death and Life of Great American Cities: The Failure of Modern Town Planning. London: Peregrine Books

Kamvasinou, K. 2017. Temporary Intervention and Long-Term Legacy: Lessons from London Case Studies. Journal of Urban Design 22 (2): 187-207.

Kickstart København. 2010. Vi investerer os ud af krisen [We invest ourselves out of the crisis] https://www.kk.dk/files/kickstart-aftal etekstpdf/download.

Kim, S. 2017. London's traditional markets; managing change and conflict in complex urban spaces, unpublished $\mathrm{PhD}$ thesis, London, UCL.
Lehrer, U., and J. Laidley. 2008. Old Mega-Projects Newly Packaged? Waterfront Redevelopment in Toronto. International Journal of Urban and Regional Research 32 (4): 786-803.

Lipton, S. 2004. Introduction. In The Value of Public Space. How High Quality Parks and Public Spaces Create Economic, Social and Environmental Value, ed. H. Woolley, S. Rose, and M. Carmona. London: CABE Space.

London Assembly. 2011. Public Life in Private Hands Managing London's Public Space. London: Greater London Authority.

Malmö Live Konserthus. 2016. Årsredovisning 2015. Malmö: Malmö Live.

Malmö stad. 2008. Konsert kongress hotell Projekt- och markanvisningstävling i Malmö. Malmö: Malmö stad.

Malmö stad. 2010a. Juryutlåtande konsert kongress hotel. Malmö: Malmö stad.

Malmö stad. 2010b. Markanvisningsavtal för konsert kongress hotell $\mathrm{mm}$. Malmö: Malmö stad.

Malmö stad. 2014. Fastighetskontoret, verksamhetsplan 2014. Malmö stad: Malmö.

Malmö stad. 2015a. Malmö och den nya befolkningsprognosen, nuläge och prognos 2016-2019. Malmö stad: Malmö stad.

Malmö stad. 2015b. Slutrapport Malmö Live-projektet. Malmö: Malmö stad.

Malmö stad. 2016. Budget 2016, med plan för 2017-2021. Malmö: Malmö stad.

Malmö stadsbyggnadskontor. 2008. Plattform för kunskapsstaden Malmö. Malmö: Malmö stad.

Malmö stadsbyggnadskontor. 2009. Det 4.stadsrum, värdibaserat udvikling. Malmö: Malmö stad.

Mayer, M. 2013. First World Urban Activism, Beyond Austerity Urbanism and Creative City Politics. City 17 (1): 5-19.

Mayor of London. 2017. The London Plan, Consultation Draft. London: Greater London Authority.

Ministry of Modernization and Local Government. 2016. Byrom - en idehåndbok. Hvordan utvikle byromsnettverk I byer og tettsteder. Ideer, strategier, eksempler [Urban public spaces - a hand book. How to develop networks of urban public spaces in cities and places. Ideas, strategies and examples] https://www.regjeringe n.no/contentassets/c6fc38d76d374e77ae5b1d8dcdbbd92a/byrom idehandbok.pdf.

Minton, A. 2014. What I Want from Our Cities in 2015: Public Spaces That are Truly Public. The Guardian, 30th December, https:// www.theguardian.com/cities/2014/dec/30/what-i-want-fromour-cities-in-2015-public-spaces-that-are-truly-public-boris-johns on-london.

Murphy, M. 2017. Marking space: Negotiating room for user efficacy in residential urban spaces ( $\mathrm{PhD}$ thesis), Department of Urban and Regional Planning, University of Life Science Norway.

National Audit Office. 2014. The Impact of Funding Reductions on Local Authorities, https://www.nao.org.uk/wp-content/uploa ds/2014/11/Impact-of-funding-reductions-on-local-authoritie s.pdf.

Nordahl, B. 2015. Kommunenes styringsmuligheter og økonomiske drivere i kompakt byutvikling. In Kompakt byutvikling. Utfordringer og muligheter, ed. G.H. Hanssen, 61-69. Oslo: Universitetsforlaget.

NOU. 2012. 14 Rapport fra 22. juli kommisjonen. (Norwegian public reports: Report from the 22. July Commission).

Nylund, K. 2014. Conceptions of Justice in the Planning of The New Urban Landscape-Recent Changes in the Comprehensive Planning Discourse in Malmö, Sweden. Planning Theory and Practice 15 (1): 41-61.

OECD. 2011. Economic Survey of Sweden 2011, Economic Surveys and Country Surveillance. Paris: OECD. 
Office for National Statistics. 2016. Retail Sales in Great Britain: Oct 2016, http://www.ons.gov.uk/businessindustryandtrade/retailindu stry/bulletins/retailsales/oct2016.

Oldenburg, R. 2000. Celebrating the Third Place. New York: Marlowe \& Company.

Peck, J. 2012. Austerity Urbanism, American Cities Under Extreme Economy. City 16 (6): 626-655.

Peck, J., and A. Tickell. 2002. Neoliberalizing Space. Antipode 34 (3): 380-404.

Pitcher, G. 2013. International money boosts London property market Architects'. Journal, January 18, https://www.architectsjourn al.co.uk/news/international-money-boosts-london-property-marke t/8641408.article.

Plimmer, J. 2016. UK parks endangered by council spending cuts, MPs warned. Financial Times, 3rd October, https://www.ft.com/conte nt/39164258-8634-11e6-a29c-6e7d9515ad15.

Realkreditrådet. 2016. https://www.realkreditraadet.dk/nyt_presse/ nyheder/store_gevinster_p\%C3\%A5_det_k\%C3\%B8benhavns ke_ejerlejlighedsmarked.

Roberts, M. 2017. 'Urban Design, Central London, and the 'Crisis' 2007-2013: Business as Usual? Journal of Urban Design 22 (2): $150-166$.

Røe, P.G. 2015. Iscenesettelser av den kompakte byen - som visuell representasjon, arkitektur og salgsobjekt. In Kompakt byutvikling. Muligheter og utfordringer, ed. G.S. Hanssen, H. Hofstad, and I.-L. Saglie. Oslo: Universitetsforlaget AS.

Saglie, I.-L., and K.H. Thorén. 2014. Perspektiv og kunnskapsproduksjon. Eksempel fra konsekvensutredninger om naturmangfold" [Perspectives and knowledge production. Nature diversity in environmental impact assessment processes]. In Konsekvensutredninger. Rettsregler, praksis og samfunnsvirkninger, ed. F. Holth and N.K. Winge. Oslo: Universitetsforlaget Oslo.

Salonen, T. 2012. Befolkningsrörelser, försörjningsvillkor och bostadssegregation - en sociodynamisk analys av Malmö [Рориlation Movements, Earning Conditions and Housing Segregation, a Socio-Dynamic Analysis of Malmö]. Malmö: Malmö stad.

Savills. 2015. Spotlight London Infrastructure: Connecting Opportunities. London: Savills World Research.

Selvig, Vilde. 2015. Utvikling av offentlige rom - kommunal styring. In Kompakt byutvikling. Muligheter og utfordringer, ed. G.S. Hanssen, H. Hofstad, and I.-L. Saglie. Oslo: Universitetsforlaget AS.

Sirowy, B. 2015. Offentlig rom i en kompakt by. In Kompakt byutvikling. Muligheter og utfordringer, ed. G.S. Hanssen, H. Hofstad, and I.-L. Saglie. Oslo: Universitetsforlaget AS.
Skanska. 2011. Ang. KKH - Erbjudande om sponsorstöd m.m. Moderbolagsgaranti, bilaga 9.15. Malmö: Skanska Sverige AB.

Socialministeriet. 2010. Byen som daglistue: Byfornyelse med plads til socialt udsatte (The city as a living room: Urban renewal with room for the marginalized) Available from: http://www.ft.dk/samli ng/20101/almdel/bou/bilag/49/964097.pdf.

Strebel, I., and J. Silberberger. 2017. Architecture Competition: Project Design and the Building Process. Abingdon: Routledge.

Syal, R., \& A. Asthana. 2017. Parliament Security to be Reviewed by Police and Authorities. March 23, https://www.theguardian.com/ uk-news/2017/mar/23/parliament-security-reviewed-after-attac k-michael-fallon.

Sydsvenskan. 2015. Så blev konserthuset Malmös dyraste bygge. 24 maj 2015.

Tonkiss, F. 2013. Austerity Urbanism and the Makeshift City. City 17 (3): 312-324.

Transport for London. 2013. Better Streets Delivered, Learning from Completed Schemes, http://www.urbandesignlondon.com/wordp ress/wp-content/uploads/better-streets-delivered-web-version.pdf.

Transport for London. 2016. Better Streets Delivered 2, Learning from Completed Schemes, unpublished.

Transport for London. 2017. Healthy Streets for London, http://conte nt.tfl.gov.uk/healthy-streets-for-london.pdf.

Watts, M. 2014. 90 per cent rise in beggar arrests is helping London drug addicts, charity says. Evening Standard, 25th July, http:// www.standard.co.uk/news/uk/90-per-cent-rise-in-beggar-arres ts-is-helping-london-drug-addicts-charity-says-9629182.html.

Williams, D. 2016. Londoners win $£ 4$ million in pothole payouts in one year. Evening Standard, 13th April, http://www.standard.co.uk/ news/london/londoners-win-4m-in-pothole-payouts-in-one-yeara3224306.html.

Wrigley N \& Lambiri D (2014) High Street Performance and Evolution, A Brief Guide to the Evidence, http://thegreatbritishhighs treet.co.uk/pdf/GBHS-HighStreetReport.pdf.

Publisher's Note Springer Nature remains neutral with regard to jurisdictional claims in published maps and institutional affiliations. 